\title{
Analisa Pembangkit Listrik Tenaga Hybrid PLTD-PLTS di Pulau Tunda Serang Banten
}

\author{
Prian Gagani Chamdareno ${ }^{1}$, Hamzah Hilal ${ }^{2}$ \\ ${ }^{1)}$ Jurusan Teknik Elektro Fakultas Teknik Universitas Muhammadiyah Jakarta, \\ ${ }^{2)}$ Badan Pengkajian dan Penerapan Teknologi \\ ${ }^{1)}$ Jl. Cempaka Putih Tengah 27 Jakarta Pusat 10510, ${ }^{2)}$ J1. M.H. Thamrin No.8 \\ Email: ${ }^{1)}$ prian.gagani@ftumj.ac.id
}

\begin{abstract}
ABSTRAK
Pulau Tunda mempunyai jumlah penduduk 2000 jiwa, dimana sistem kelistrikannya disuplai oleh genset dengan kapasitas $100 \mathrm{~kW}$ yang beroperasi selamal3 jam setiap hari. Dengan sumber daya Energi Baru Terbarukan (EBT) yang dapat dikembangkan yaitu energi surya dengan potensi rata-rata sebesar 5,08 $\mathrm{KWh} / \mathrm{m} 2 /$ hari. Tujuan dari penelitian ini adalah mendapatkan kapasitas pembangkit hibrid dari PLTD-PLTS, yang berdasarkan Net Present Cost (NPC) dan hasil analisis. Metode yang digunakan dalam penelitian ini yaitu melakukan simulasi dengan menggunakan software HOMER. Berdasarkan hasil simulasi tersebut kemudian akan dilakukan analisis untuk mengukur seberapa layak sistem pembangkit hibrid ini apabila diterapkan. Dari hasil simulai sistem pembangkit hirbrida PLTD-PLTS yang direncanakan didapat hasil total produksi listrik 206.961 kWh/tahun dengan kondtribusi PLTD 81,3\% dan kontirbusi PLTS 18,7\%, dimana NPC sebesar \$ 2.180.000, biaya listrik $\$ 0.919$ per $\mathrm{kWh}$, kelebihan listrik sebesar $42.711 \mathrm{kWh} /$ tahun, emisi CO2 yang dihasilkan pada sistem ini adalah sebesar 147 ton pertahun, terjadi penurunan jumlah emisi CO2 sebesar 27 ton pertahun atau 15,5\%..
\end{abstract}

Kata Kunci : PLTD,PLTS, Simulasi, NPC, emisi CO2

\section{PENDAHULUAN}

Pulau Tunda adalah salah satu pulau di Indonesia dengan posisi geografis $5^{0} 48$ ' 43 ” LS dan $106^{\circ} 16^{\prime} 47^{\prime \prime}$ BT (lihat peta satelit). Total luas Pulau Tunda 260 ha dihuni oleh lebih dari 2.000 Jiwa, aktivitas ekonomi masyarakat bertumpu pada perikanan. Pemerintah Provinsi Banten menetapkan Pulau Tunda sebagai salah satu daerah tujuan pariwisata.

Energi terlibat pada semua aspek kehidupan [1]. Energi memainkan peran yang sangat penting untuk Negara dan harus dikelola dengan cara yang efisien[2]. Saat ini energi listrik di Pulau Tunda dipasok oleh 1 unit Pembangkit Listrik Tenaga Diesel (PLTD) yang memiliki kapasitas terpasang $100 \mathrm{~kW}$. Namun demikian PLTD hanya beroperasi 13 jam per hari yaitu mulai dari jam 17.00 sampai jam 07.00 dengan beban puncak sebesar $65 \mathrm{~kW}$. Mengingat Pulau Tunda merupakan salah satu daerah wisata, maka infrastruktur kelistrikannya perlu diperhatikan lebih komprehensif untuk mendorong pertumbuhan ekonomi masyarakat di Pulau tersebut. Sesuai program pemerintah dalam hal hemat energi dank arena PLTD menghasilkan banyak emisi $\mathrm{CO}_{2}$, maka penyediaan energi listrik diusahakan memanfaatkan seoptimum mungkin sumber-sumber energi terbarukan setempat (Pulau Tunda), dalam hal ini energi surya dan energi angin. Untuk itu perlu dilakukan studi terlebih dahulu guna pengoperasian PLTD yang diintegrasikan dengan Pembangkit Listrik Tenaga Surya (PLTS). Energi matahari adalah cahaya radian dan panas yang berasal dari matahari yang dimanfaatkan untuk teknologi yang selalu berkembang seperti pemanasan oleh matahari dan fotovoltik[3]. Teknologi baru yang disebut pengonsentrasi daya matahari memiliki potensi yang sangat besar bagi negara dengan sinar matahari yang melimpah dan langit yang cerah[4]. Pembangkit listrik tersebut dinamakan Pembangkit Listrik Tenaga Hibrida (PLTH). Pengembangan system tenaga hibrid untuk aplikasi pada rumah tangga, institusi pendidikan, dan industri memerlukan pengetahuan dasar pada bidang teknologi, ketersediaan sumber daya alam, ekonomi dan peraturan kebijakan[5]. Power grid di Amerika Serikat dan negara negara lain di dunia telah mengalami pengingkatan pada frekuensi, intensitas dan durasi pemadaman sehingga memaksa peninjauan ulang dari kebijakan energi dan peraturan-peraturan[6].

Keluaran studi ini berupa unjuk kerja atau kemampuan PLTH, yaitu integrasi antar PLTD yang berbasis BBM, dengan PLTS dan PLTB yang berbasis energi terbarukan, berupa total daya PLTH, jumlah BBM yang dapat dihemat, kelebihan energi listrik yang dihasilkan, biaya pembangkitan listrik dan keluaran emisinya. Pengelolaan data dalam studi ini seluruhnya berbantuan perangkat lunak HOMER. 
RESISTOR (elektRonika kEndali telekomunikaSI tenaga liSTrik kOmputeR) Vol. 1 No. 1 e-ISSN :

Tujuan penelitian ini adalah mendapatkan hasil simulasi sistem PLTH (PLTD-PLTS) dengan menggunakan perangkat lunak Homer yang nantinya dapat diterapkan di Pulau Tunda Serang Banten.

Pembangkit listrik tenaga hibrida (PLTH) adalah gabungan atau integrasi antara beberapa jenis pembangkit listrik berbasis BBM dengan pembangkit listrik berbasis energi terbarukan umumnya sistem pembangkit yang banyak digunakan untuk PLTH adalah generator diesel, pembangkit listrik tenaga surya (PLTS), mikrohidro, Dalam studi ini dibuat hibrida PLTD-PLTS. PLTH ini dioperasikan untuk memikul beban. Saat ini elektronika berbahan semikonduktor organik menjadi perhatian karena fleksibel dan mudah di proses [7], [8], [9].

Kontribusi daya masing-masing jenis pembangkit setiap saat tidak tetap, mengingat PLTS sangat tergantung dari kondisi alam. Pada siang hari, ketika cuaca cerah, PLTS dapat beroperasi maksimum dan pada malam hari PLTS sama sekali tidak beroperasi, tetapi digantikan oleh baterai yang menyimpan energi listrik dari PLTS sepanjang siang hari.. Pembangkit berikutnya, PLTD adalah pembangkit instan yang dapat beroperasi penuh selama 24 jam. Namun sesuai dengan tujuan pengoperasian PLTH, yaitu menghemat BBM dan mengurangi emisi $\mathrm{CO}_{2}$, maka pengoperasian PLTD merupakan variabel terakhir yang mengikuti perubahan suplai daya PLTS, sehinga kontribusi dayanya pun tergantung dari suplai daya pembangkit listrik tersebut. Dengan pengoperasian PLTS yang terintegrasi pada PLTH, maka pemakaian $\mathrm{BBM}$ dan emisi $\mathrm{CO}_{2}$ dapat dikurangi.

\section{METODOLOGI}

Data beban listrik yang didapatkan dan digunakan hanya data beban selama sehari. Data beban listrik tersebut mewakili beban listrik selama setahun. Umumnya Beban listrik di Pulau Tunda terdiri dari lampu, TV, pompa air, dll.

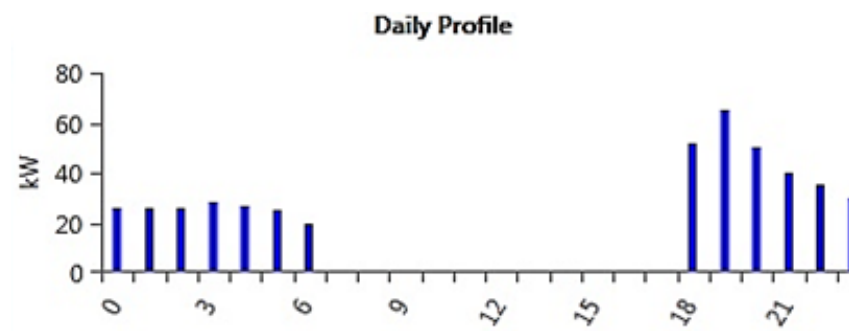

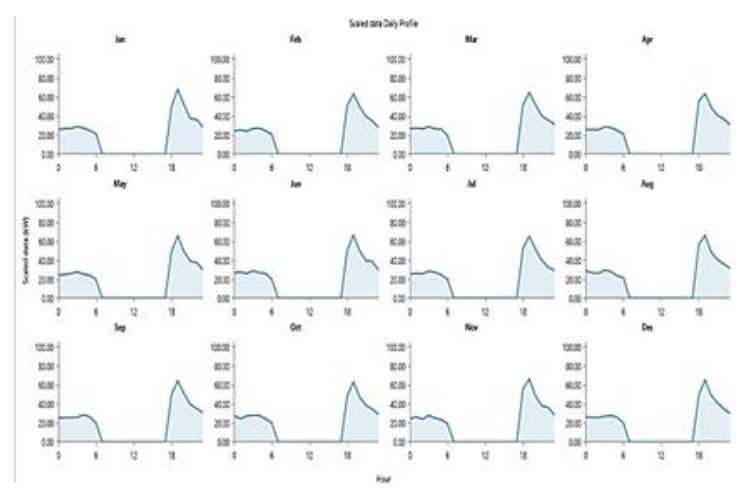

Gambar 2 Grafik beban selama setahun.

Pulau Tunda terletak pada kooardinat $\left(5^{0} 48,7^{\prime} \mathrm{S}, 106^{0} 16,9^{\prime} \mathrm{E}\right)$. Data radiasi matahari didapatkan melalui "Get Data Via Internet" dimana Homer akan secara otomatis masuk dalam situs resmi Badan Anatariksa Amerika Serikat (NASA Surface Meteorolgy), kemudian akan didapatkan rata-rata radiasi matahari per tahun sekitar 5,08 $\mathrm{kWh} / \mathrm{m} 2 / \mathrm{d}$. Tabel 1 menunjukkan nilai radiasi matahari daerah Pulau Tunda, Tirtayasa, Serang, Banten, Indonesia, berdasarkan pengamatan NASA.

Tabel 1 Rata-rata radiasi matahari per tahun.

\begin{tabular}{|c|c|c|}
\hline Month & $\begin{array}{l}\text { Clearness } \\
\text { Index }\end{array}$ & $\begin{array}{l}\text { Daily Radiation } \\
\text { (kWh } / \mathrm{m}^{2} / \text { day) }\end{array}$ \\
\hline January & 0.456 & 4.850 \\
\hline February & 0.465 & 4.990 \\
\hline March & 0.507 & 5.330 \\
\hline April & 0.512 & 5.050 \\
\hline May & 0.529 & 4.800 \\
\hline June & 0.531 & 4.580 \\
\hline July & 0.552 & 4.870 \\
\hline August & 0.567 & 5.400 \\
\hline September & 0.567 & 5.810 \\
\hline October & 0.517 & 5.480 \\
\hline November & 0.473 & 5.010 \\
\hline December & 0.453 & 4.770 \\
\hline
\end{tabular}

Gambar 1 Grafik beban harian. 
RESISTOR (elektRonika kEndali telekomunikaSI tenaga liSTrik kOmputeR) Vol. 1 No. 1 e-ISSN :

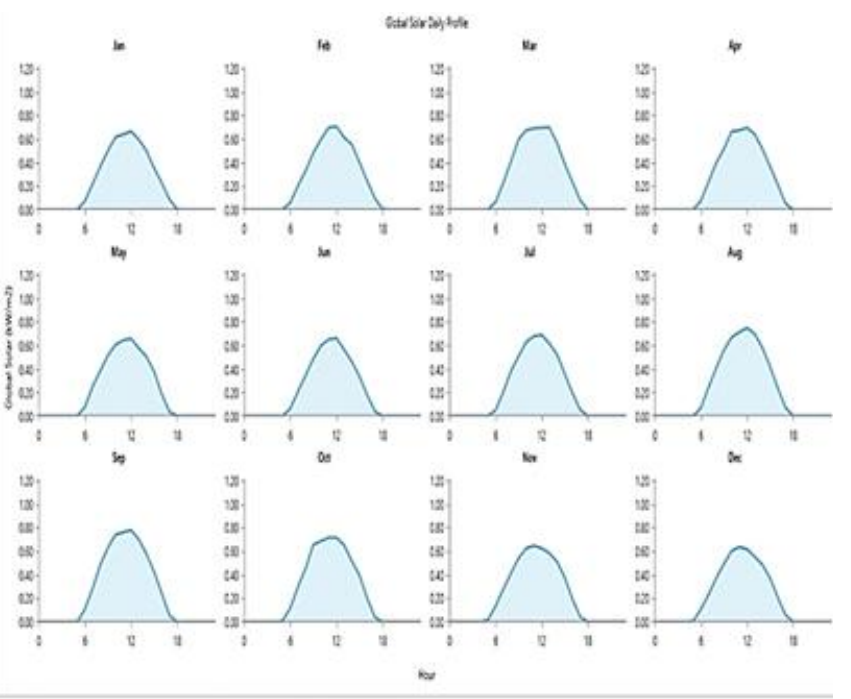

Gambar 3 Grafik rata-rata radiasi matahari selama setahun.

Generator yang digunakan adalah model Generic atau dalam realitasnya merk Marathon tipe MP-H-100-4. Generator dirancang untuk menyupali beban dan sebagian beban dilayani oleh energi angin atau surya. Daya generator direncanakan sebesar $100 \mathrm{~kW}$ karena dapat memenuhi beban puncak dari beban. Biaya generator sebesar $\$ 11,870$, biaya pengganti sebesar $\$ 9,496$ dan biaya operasional sebesar \$2,3/jam. Besarnya pengeluaran biaya dari generator ditunjukkan oleh Tabel 2.

Homer menyediakan parameter masukan generator, yang terdiri dari 4 macam, yaitu baiaya (cost), bahan bakar (fuel), jadwal pengoperasian (schedule), emisi bahan bakar (emission).

Tabel 2 Parameter masukan generator.

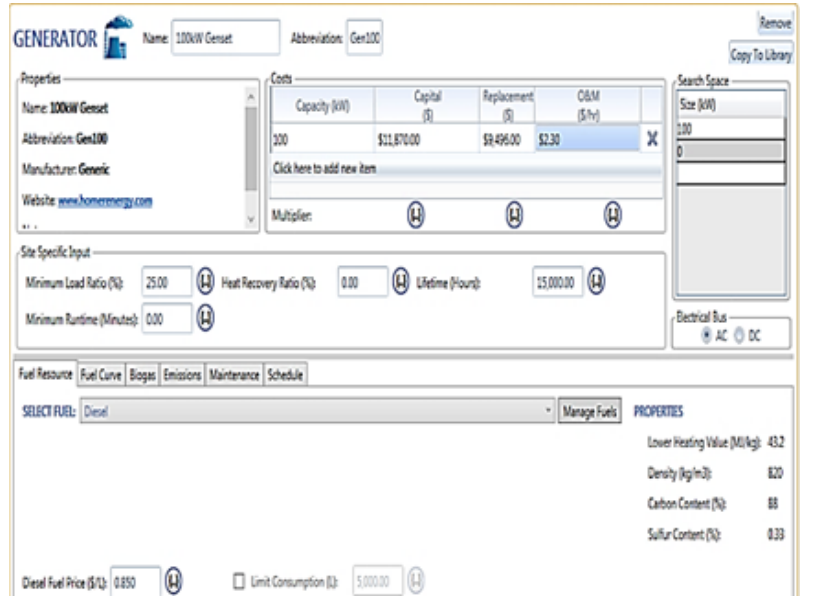

Konverter ini berfungsi untuk mengubah tegangan ac ke dc atau sebaliknya, jenis konverter yang digunakan adalah Leonics S219CPH 5kW $48 \mathrm{Vdc} 60 \mathrm{~A}$ Inverter charger. Komponen pendukung converter ini terdiri dari inverter dan rectifier. Masing-masing memiliki efisiensi sebesar $96 \%$ dan $94 \%$. Biaya untuk pembelian konverter sebesar $\$ 900$, umur pakai selama 10 tahun.

Tabel 3 Parameter masukan converter.

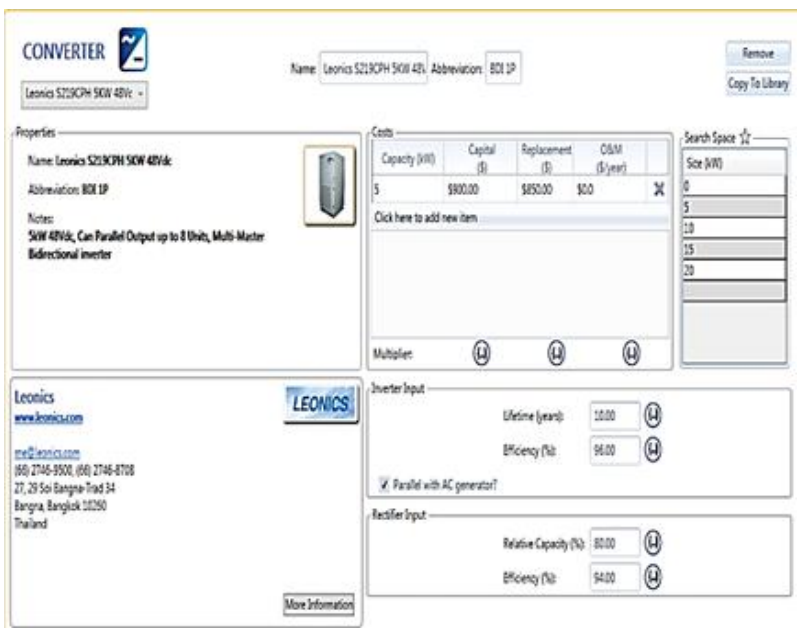

Baterai yang digunakan dalam simulasi ini adalah Trojan, terdiri dari $2 \times 6 \mathrm{~V} 420 \mathrm{Ah}$, charger baterai 12 Volt dan sambungan baterai (battery interconnect $25 \mathrm{~mm}$ ), sambungan baterai digunakan untuk menghubungkan baterai sehingga kapasitas baterai menjadi $12 \mathrm{~V} 420 \mathrm{Ah}$. Baterai Trojan dipilih karena dapat tahan lama, harga murah, instalasi mudah. Jumlah baterai yang direncanakan yaitu 0,50,100,150,200. Biaya baterai $\$ 419$.

Tabel 4 Parameter masukan Baterai

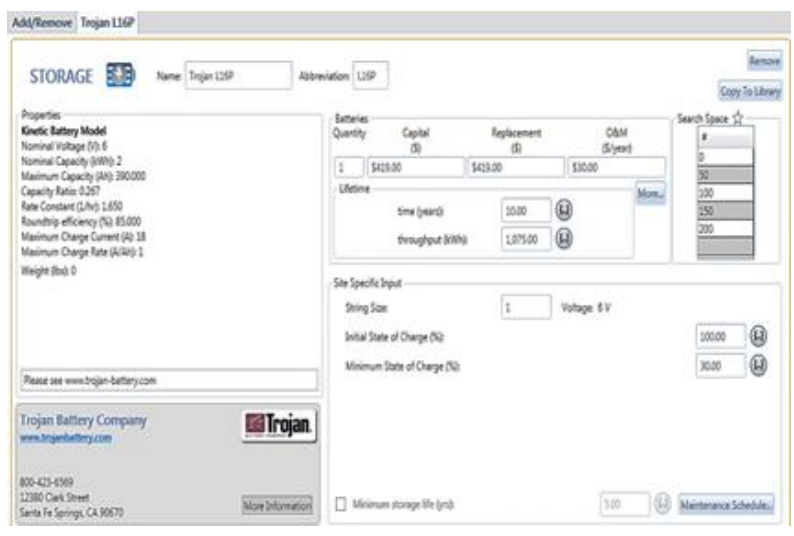

Bahan bakar yang digunakan untuk genset berupa solar. Berdasarkan data lapangan harga solar di Pulau Tunda sebesar Rp 8.000,- atau \$ 0.58 (kurs rupiah 13.700). 
RESISTOR (elektRonika kEndali telekomunikaSI tenaga liSTrik kOmputeR) Vol. 1 No. 1 e-ISSN :

Tabel 5. Parameter masukan bahan bakar.

\begin{tabular}{|c|c|}
\hline \multicolumn{2}{|c|}{ 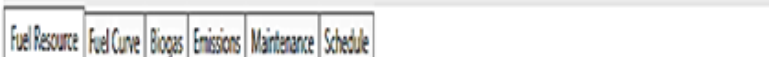 } \\
\hline seftput: Dies & $\cdot \sqrt{\text { Nerogefus }}$ \\
\hline
\end{tabular}

Komponen utama dari sistem tenaga hibrida genset - surya untuk Pulau Tunda adalah generator dan panel surya, sedangkan komponen pendukung dari sistem adalah konverter, beterai bank. Gambar 4 adalah sistem tenaga hibrida PLTD-PLTS yang di gambarkan oleh Homer.

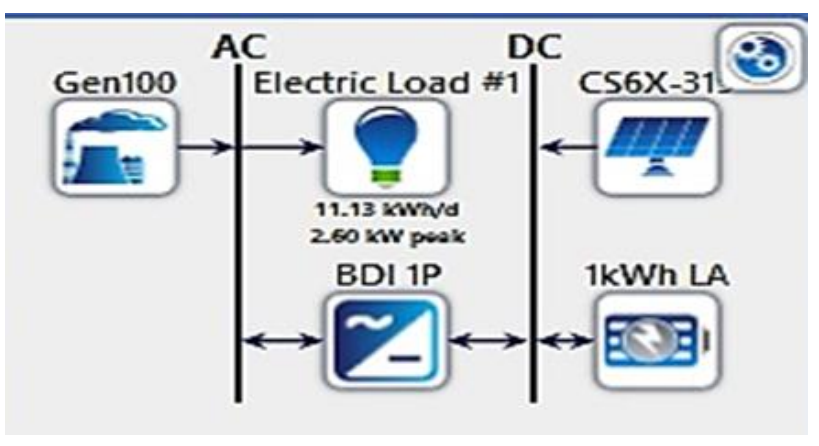

Gambar 4 Sistem Hibrida PLTD-PLTS.

Tabel 6 Biaya Komponen Hibrida Genset-Surya.

\begin{tabular}{|c|c|c|c|c|c|}
\hline Komponen & Daya & Modal & $\begin{array}{c}\text { Blaya } \\
\text { Pengganti }\end{array}$ & $\begin{array}{l}\text { Uperası \& } \\
\text { Perawatan }\end{array}$ & Umur Pakai \\
\hline Generator & $100 \mathrm{~kW}$ & $\$ 11870$ & $\$ 9496$ & \$2.3.jam & $15000 \mathrm{jam}$ \\
\hline$\overline{\text { PV }}$ & $0,315 \mathrm{~kW}$ & 5280 & $\$ 280$ & so & 25 th \\
\hline Konverter & $5 \mathrm{~kW}$ & $\$ 900$ & 5850 & So & 10 th \\
\hline Baterai & $360 \mathrm{Ah} 6 \mathrm{~V}$ & $\$ 419$ & $\$ 419$ & S50th & 10 th \\
\hline
\end{tabular}

Panel sel surya yang digunakan adalah CanadianSolar MaxPower CS6X-315 [15]. Satu panel sel surya berkapasitas $315 \mathrm{~W}$ dengan harga $\$ 280$. Unit satuan Watt-peak adalah satuan daya (Watt) yang dapat dibangkitkan oleh modul

photovoltaic dalam keadaan standar uji Standard Test Condition (STC). Parameter masukan sel surya ditunjukkan pada Tabel 7.

Dalam sebuah sistem, panel surya ini dapat disusun dan dirangkai menjadi beberapa buah panel, sesuai dengan daya yang dibutuhkan. Panel surya ini memiliki kelebihan yaitu struktur lapisan film photovoltaic yang tahan cuaca

Tabel 7 Parameter masukan panel surya.

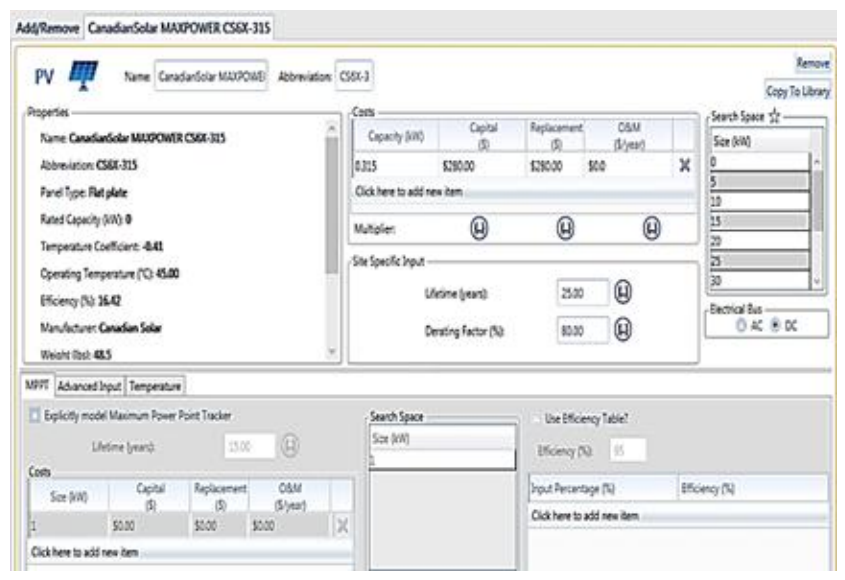

Suku bunga per tahun adalah nilai nominal suku bunga dikurangi nilai inflasi. Suku bunga per tahun pada negara Indonesia per bulan November sebesar $4,75 \%$. Nilai yang tepat untuk suku bunga sangatlah bergantung kepada kondisi makroekonomi saat ini, kekuatan finansial dan berbagai kebijakan lainnya. Tabel 8 menunjukkan parameter masukan suku bunga dan jangka waktu proyek.

Umur proyek (tahun) adalah perkiraan lamanya umur proyek yang akan dibangun. Lamanya umur proyek dapat ditentukan dan disesuaikan dengan garansi komponen terlama. Pada sistem ini diperkirakan umur proyek berlangsung 25 tahun, disesuaikan dengan garansi sel surya. Homer menggunakan umur proyek untuk menghitung biaya selama setahun dan biaya dari masing-masing komponen.

Tabel 8 Faktor Ekonomi.

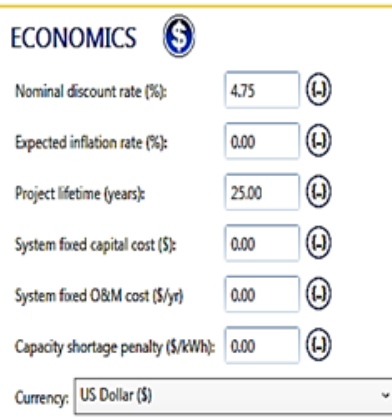


RESISTOR (elektRonika kEndali telekomunikaSI tenaga liSTrik kOmputeR) Vol. 1 No. 1 e-ISSN :

Parameter masukan kontrol sistem menetapkan bagaimana Homer memodelkan pengoperasian dari baterai bank dan generator. Sistem ini menggunakan cara Load Following yang artinya pengisian baterai dilakukan dengan tenaga hibrida (sel surya /angin). Cara ini dipilih karena sistem memiliki sumber energi sel surya atau angin yang akan mengisi baterai ketika daya keluaran (Output) melibihi beban yang dibutuhkan.

Tabel 9 Parameter masukan kontrol sistem pada homer.

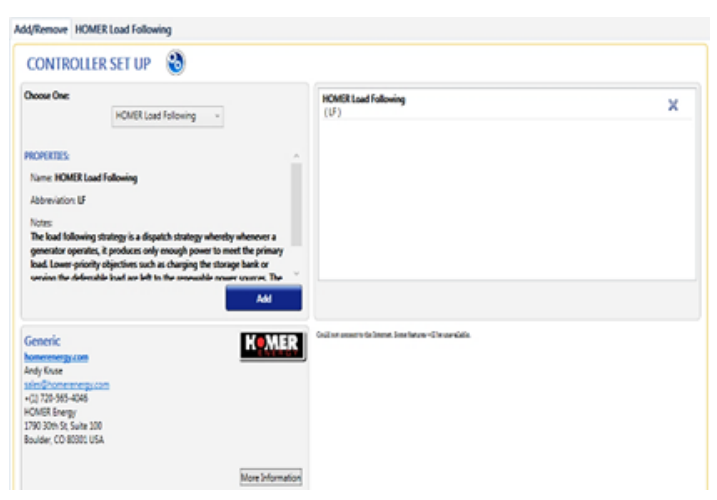

Constraint adalah kondisi dimana konfigurasi sistem sangat memungkinkan untuk dirancang dan dibuat. Konfigurasi sistem yang tidak memungkinkan tidak akan ditampilkan didalam hasil analisa sensitifitas. Tabel 10 menunjukkan parameter masukan constraint yang terdapar pada Homer. Maximum annual capacity shortage adalah presentasi jumlah kekurangan energi listrik pada sistem setiap harinya. Diasumsikan nilainya sebesar $10 \%$. Minimum renewable fraction adalah presentasi jumlah minimum energi terbarukan dengan generator. Diasumsikan nilai renewable fraction sebesar $10 \%$. Tenaga cadangan dibutuhkan untuk mengantisipasi apabila terjadi kenaikan beban secara tiba-tiba dan penurunan energi keluaran (output) pada tenaga hibrida. Tenaga cadangan ini dapat dikendalikan dengan mengatur data beban per jam, data beban puncak, data energi keluaran turbin angin dan data keluaran pada panel sel surya yaitu :

Load in current time step (\%) adalah jumlah persentasi besarnya nilai yang ditambahkan pada beban setiap jamnya. Besarnya Load in current time step pada perancangan sebesar $10 \%$, untuk mengantisipasi terjadinya kenaikan beban sebesar 10\%. Annual peak load adalah persentasi besarnya nilai yang ditambahkan hanya pada beban puncak. Solar power output adalah persentasi besarnya nilai untuk mengantisipasi apabila energi keluaran sel surya menurun sebesar $25 \%$. Wind power output adalah persentasi besarnya nilai untuk

mengantisipasi apabila energi keluaran turbin angin menurun sebeusar $25 \%$

Tabel 10 Parameter masukan faktor constraint.

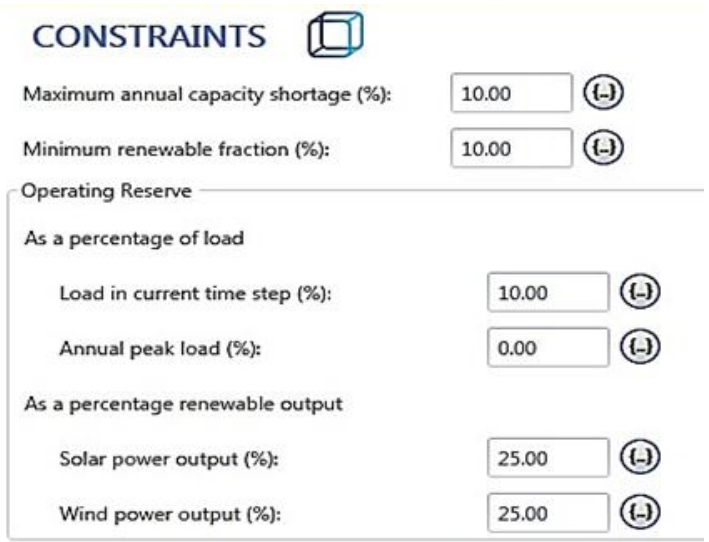

Penelitian ini dilakukan dengan tahapan sebagai berikut :

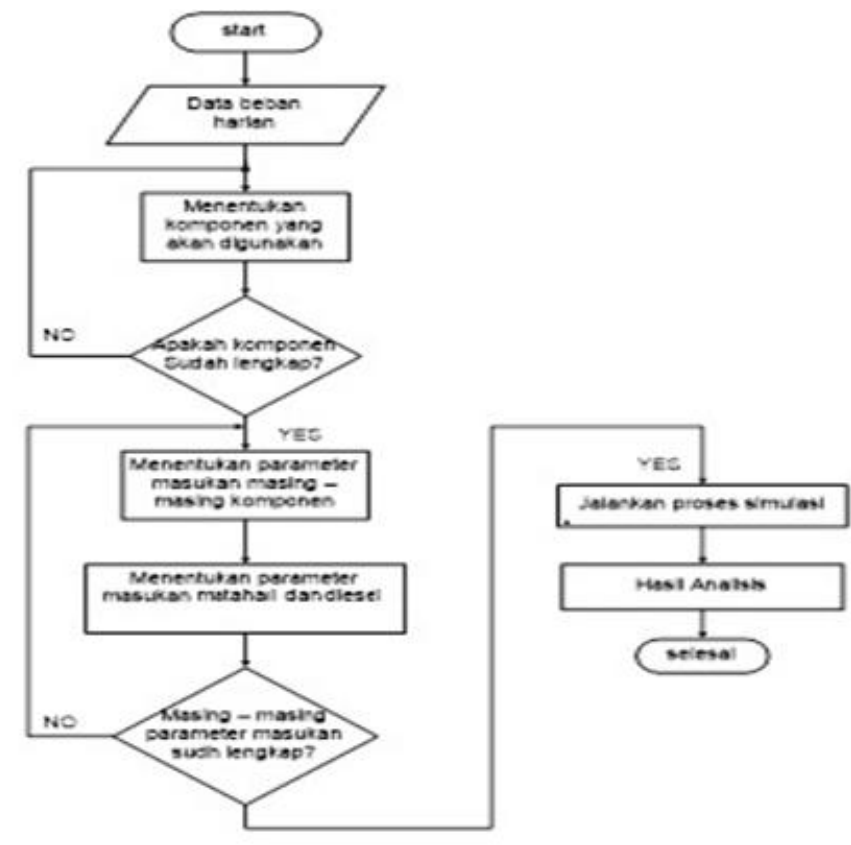

Gambar 5 Diagram Alir Simulasi.

Perancangan sistem ini menggunakan software HOMER. Simulasi ini akan mendapatkan hasil yang optimum pada PLTH :

Langkah-langkah yang dilakukan adalah :

1. Pada simulasi ini langkah awal adalah dengan memasukan data beban listrik.

2. Menentukan komponen-komponen PLTH yang akan di gunakan.

3. Mengecek kelengkapan komponen-komponen pada PLTH. 


\section{e-ISSN :}

4. Menentukan parameter masukan masing-masing komponen.

5. Menentukan parameter masukan faktor sumber daya matahari

6. Mengecek masing-masing parameter masukan faktor sumber daya matahari.

7. Menjalankan proses simulasi dengan HOMER.

8. Mendapatkan hasil simulasi.

\section{HASIL DAN PEMBAHASAN}

Analisis hasil simulasi pada kondisi awal ini adalah sebagai pembanding atau yang akan dijadikan patokan untuk menganalisis sistem PLTH optimal hasil simulasi kondisi kedua, adapun hasilnya yaitu :

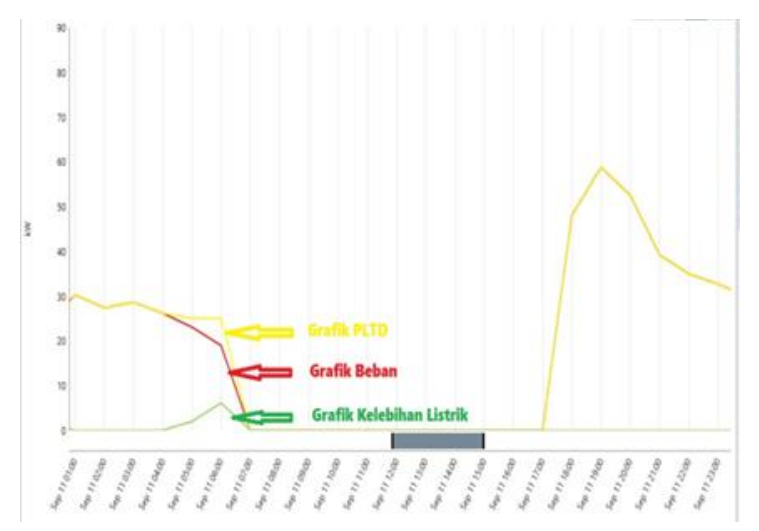

Gambar 6 Kondisi Beban Harian - Daya Keluaran PLTD 100kW- Kelebihan Listrik Yang Tidak Terpakai.

Gambar 6 diatas adalah kondisi suplai listrik pada tanggal 11 September 2016, dapat dilihat PLTD $100 \mathrm{~kW}$ beroperasi pada jam 17.00 sampai jam 07.00. Keluaran daya maksimum sebesar $65 \mathrm{~kW}$ pada jam 19.00. Pada jam 06.00 terdapat kelebihan listrik sebesar $5 \mathrm{~kW}$ dikarenakan oleh daya yang dihasilkan oleh PLTD sebesar $25 \mathrm{~kW}$ sedangkan penggunaan beban hanya sebesar $20 \mathrm{~kW}$. Kelebihan listrik ini terjadi karena listrik yang diproduksi oleh PLTD $100 \mathrm{~kW}$ berlebihan dibandingkan dengan beban yang ada. Pada kondisi awal ini kelebihan energi listrik tersebut tidak dapat dimanfaatkan, karena tidak terdapat baterai sebagai tempat penyimpanan energi listrik pada sistem ini.

Dampak Lingkungan (Emisi)

Ketika kondisi awal atau nilai kontribusi energi terbarukan $0 \%$, maka didapatkan tingkat emisi $\mathrm{CO}_{2}$ dan $\mathrm{SO}_{x}$ pada pemakaian bahan bakar PLTD. Emisi $\mathrm{CO}_{2}$ sebesar 174 ton per tahun. Hal yang sama terjadi pada emisi $\mathrm{SO}_{\mathrm{x}}$, ketika kondisi awal nilai emisi $\mathrm{SO}_{\mathrm{x}}$ adalah $350 \mathrm{~kg}$ per tahun.
Pada kondisi ini, simulasi sistem PLTH PLTD-PLTS. Dari hasil simulasi didapat hasilnya sebagai berikut:

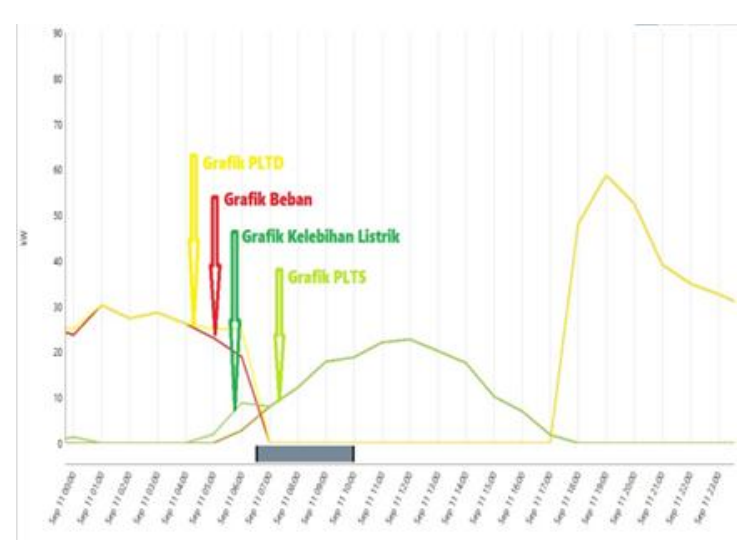

Gambar 7 Kondisi Beban Harian - Daya Keluaran PLTD-PLTS - Kelebihan Listrik Yang Tidak Terpakai

Gambar 7 adalah kondisi suplai listrik pada tanggal 11 September 2016, dapat dilihat PLTS tidak beroperasi pada jam 18.00 sampai dengan jam 05.00. Daya keluaran daya maksimum PLTS adalah sebesar $20 \mathrm{~kW}$ terjadi pada pukul 12.00. PLTD 100 $\mathrm{kW}$ tidak beroperasi pada pukul 07.00 - 17.00. Kelebihan listrik yang tidak terpakai pada sistem ini sebesar $42.711 \mathrm{kWh}$ pertahun atau 20,6\% hal ini terjadi karena listrik yang diproduksi PLTS selama satu tahun berlebihan dibandingkan dengan beban yang ada. Ketika disain PLTH disimulasi dan analisa dengan nilai kontribusi energi terbarukan, maka didapatkan tingkat emisi $\mathrm{CO}_{2}$ dan $\mathrm{SO}_{\mathrm{x}}$ turun seiring dengan menurunnya pemakaian bahan bakar pada PLTD. Ketika kontribusi energi PLTS 0\% nilai emisi $\mathrm{CO}_{2}$ adalah 174 ton pertahun. Nilai $\mathrm{CO}_{2}$ menjadi 147 ton pertahun ketika kontribusi enegi PLTS $18,7 \%$ berkurang sebanyak $15,5 \%$ atau 27 ton pertahun. Hal yang sama juga terjadi pada emisi $\mathrm{SO}_{\mathrm{x}}$, ketika kontribusi energi PLTS 0\% nilai emisi $\mathrm{SO}_{\mathrm{x}}$ adalah $350 \mathrm{~kg}$ pertahun. Nilai emisi $\mathrm{SO}_{\mathrm{x}}$ menjadi $295 \mathrm{~kg}$ pertahun ketika kontribusi energi PLTS $18,7 \%$ berkurang sebanyak $15,7 \%$ atau $55 \mathrm{~kg}$ pertahun.

\section{KESIMPULAN}

Dari hasil analisis yang telah dilakukan secara keseluruhan, ketiga konfigurasi sistem PLTH di Pulau Tunda Serang Banten dapat diambil kesimpulan bahwa total produksi listrik yang di hasilkan pada hibrida PLTD-PLTS pertahun yaitu sebesar $206.961 \mathrm{kWh} /$ tahun. Kontribusi PLTS terhadap sistem PLTH sebesar $18,7 \%$ atau 38.793 $\mathrm{kWh} /$ tahun dengan waktu operasi pukul 05.00-18.00 
RESISTOR (elektRonika kEndali telekomunikaSI tenaga liSTrik kOmputeR) Vol. 1 No. 1 e-ISSN :

setiap hari dengan jumlah jam operasi 4.830 jam/tahun. Sedangkan PLTD 81,3\% atau 168.168 $\mathrm{kWh} /$ tahun dengan waktu operasi 17.00-07.00 setiap hari atau jumlah jam operasi 4.745 jam/tahun. Konfigurasi ini memiliki nilai NPC \$ 2.180.000 dan biaya listrik $\$ 0.919$ per $\mathrm{kWh}$. Kelebihan energinya selama setahun sebesar $42.711 \mathrm{kWh} /$ tahun. Dampak lingkungan yang dapat dikurangi dengan menerapkan sistem PLTD-PLTS, emisi $\mathrm{CO}_{2}$ yang dihasilkan pada sistem ini adalah sebesar 147 ton pertahun, terjadi penurunan junlah emisi $\mathrm{CO}_{2}$ sebesar 27 ton pertahun atau $15,5 \%$ dari kondisi awal jumlah emisi $\mathrm{CO}_{2}$ sebesar 174 ton pertahun.

\section{DAFTAR PUSTAKA}

[1] Budiyanto and Fadliondi, "The Improvement of Solar Cell Output Power Using Cooling and Reflection from Mirror," Int. J. Power Electron. Drive Syst., vol. 8, no. 3, pp. 13201326, 2017.

[2] K. Kaur, G. Singh Brar, and M. T. Scholar, "Solar-Biogas-Biomass Hybrid Electrical Power Generation for a Village (a case study)," Int. J. Eng. Dev. Res., vol. 4, no. 1, pp. 23219939, 2016.

[3] M. Mustafa, V. Sunil, and U. Bhasker, "Hybrid Power Generation By Solar Tracking and Vertical Axis Wind Turbine ( Design and Analysis )," Int. Res. J. Eng. Technol., vol. 4, no. 8, 2017.

[4] H. Hong, S. Peng, Y. Zhao, Q. Liu, and H. Jin, "A typical solar-coal hybrid power plant in China," Energy Procedia, vol. 49, pp. 17771783, 2013.

[5] G. Sandeep and V. S. Vakula, "Optimal combination and sizing of a standalone hybrid power system using HOMER," 2016 Int. Conf. Electr. Electron. Optim. Tech., pp. 4141-4144, 2016.

[6] J. A. Weber, D. W. Gao, and T. Gao, "Affordable mobile hybrid integrated renewable energy system power plant optimized using HOMER Pro," NAPS 2016 48th North Am. Power Symp. Proc., pp. 1-6, 2016.

[7] Fadliondi, H. Isyanto, and P. G. Chamdareno, "The comparison of organic field effect transistor (OFET) structures," in 2017 2nd International Conference on Frontiers of Sensors Technologies (ICFST), 2017, pp. 6-9.
[8] F. Fadliondi and B. Budiyanto, "Transistor Efek Medan Berbasis Semikonduktor Organik Pentacene untuk Sensor Kelembaban," J. Nas. Tek. Elektro dan Teknol. Inf., vol. 6, no. 2, pp. 204-209, 2017.

[9] Fadliondi, M. K. Biddinika, and S.-I. Ohmi, "The humidity dependence of pentacene organic metal-oxide-semiconductor fieldeffect transistor," Telkomnika (Telecommunication Comput. Electron. Control., vol. 15, no. 2, pp. 578-583, 2017. 
RESISTOR (elektRonika kEndali telekomunikaSI tenaga liSTrik kOmputeR) Vol. 1 No. 1 e-ISSN : 